\title{
New records of Demospongiae (Porifera) from Reserva Marina EI Pelado (Santa Elena, Ecuador), with description of Tedania (Tedania) ecuadoriensis sp. nov.
}

\author{
Karla B. Jaramillo ${ }^{1,2}$, Báslavi Cóndor-Luján³ ${ }^{3}$ Belinda Longakit ${ }^{2}$, Jenny Rodriguez', \\ Olivier P. Thomas ${ }^{4}$, Grace McCormack ${ }^{2}$, Eduardo Hajdu ${ }^{5}$ \\ I ESPOL Polytechnic University, Escuela Superior Politécnica del Litoral, ESPOL. Centro Nacional de Acui- \\ cultura e Investigaciones Marinas, CENAIM. Campus Gustavo Galindo Km. 30.5 Via Perimetral, P.O. Box \\ 09-01-5863, Guayaquil, Ecuador 2 Zoology, School of Natural Sciences and Ryan Institute, National Universi- \\ ty of Ireland Galway, University Road, H91 TK33 Galway, Ireland 3 Universidad Cientifica del Sur, Facultad \\ de Ciencias Veterinarias y Biológicas, Carrera de Biología Marina, Antigua Panamericana Sur Km. 19, Villa \\ El Salvador, Lima, Perú 4 Marine Biodiscovery, School of Chemistry and Ryan Institute, National University of \\ Ireland Galway, University Road, H91 TK33 Galway, Ireland 5 Museu Nacional, Universidade Federal do Rio \\ de Janeiro, Depto. Invertebrados, Quinta da Boa Vista, s/n, 20940-040, Rio de Janeiro, RJ, Brazil
}

Corresponding author: Karla B. Jaramillo (kbjarami@espol.edu.ec)

Academic editor: Ya. Mutafchiev | Received 20 May 2020 | Accepted 23 October 2020 | Published 19 January 2021

http://zoobank.org/2D67157E-B9B3-4601-8212-3633DD3EBD87

Citation: Jaramillo KB, Cóndor-Luján B, Longakit B, Rodriguez J, Thomas OP, McCormack G, Hajdu E (2021) New records of Demospongiae (Porifera) from Reserva Marina El Pelado (Santa Elena, Ecuador), with description of Tedania (Tedania) ecuadoriensis sp. nov.. ZooKeys 1011: 101-120. https://doi.org/10.3897/zookeys.1011.54485

\begin{abstract}
The first taxonomic descriptions of the sponge diversity at El Pelado Marine Protected Area in the province of Santa Elena, Ecuador is reported. Tedania (Tedania) ecuadoriensis Jaramillo \& Hajdu, sp. nov. is described from its shallow waters. In addition, Callyspongia (Callyspongia) aff. californica (sensu Cruz-Barraza and Carballo 2008; non sensu Dickinson 1945) and Cliona aff. euryphylle are reported for the first time. The former species is likely distributed over 4,000 km along the Tropical Eastern Pacific, whereas the latter might be an example of a trans-isthmian lineage. An amended diagnosis for Callyspongia (Callyspongia) and an updated identification key for the subgenera of Callyspongia are provided.
\end{abstract}

\section{Keywords}

Callyspongia, Cliona, sponge taxonomy, Tropical Eastern Pacific

Copyright Karla B. Jaramillo et al. This is an open access article distributed under the terms of the Creative Commons Attribution License (CC BY 4.0), which permits unrestricted use, distribution, and reproduction in any medium, provided the original author and source are credited. 


\section{Introduction}

Sponges represent a key component of marine ecosystems and exhibit high diversity and abundance in some oceans, including tropical, temperate and polar regions (Bell and Barnes 2003; Bell and Smith 2004; Carballo et al. 2008; Hajdu et al. 2013; Hajdu et al. 2015; Pacheco et al. 2018). Due to the broad substrate cover and filtration capacity of sponges, marine ecosystems in general will likely be affected by changes in the geographic distribution of these organisms (Bell and Smith 2004; Bell 2007; Carballo et al. 2008; Cruz-Barraza and Carballo 2008). These reasons, together with sponges' known biomedical potential, have attracted the interest of researchers to explore the distribution and diversity of sponges in maritime ecoregions around the planet.

Despite published reports on sponge distribution in the Pacific Ocean, knowledge gaps still exist in the eastern Pacific, and especially along the coast of Ecuador, where descriptive studies have rarely been conducted (Miloslavich et al. 2011). A recent increase in taxonomic effort in this large area started in Chile (Hajdu et al. 2006; Azevedo et al. 2009; Willenz et al. 2009; Hajdu et al. 2013; Fernandez et al. 2016; Costa et al. 2020), and more recently expanded to the Peruvian coast (Aguirre et al. 2011; Azevedo et al. 2015; Hajdu et al. 2015; Cóndor-Luján et al. 2019; Recinos et al. 2020). This collective effort has unveiled a high diversity and abundance of sponges in shallow south-eastern Pacific waters. Since 2003 in Chile, and 2007 in Peru, nearly 3,000 specimens have been collected, with new species reported. Taxonomic identifications of this large collection are still in progress and will certainly lead to many more discoveries.

In this regard, and despite its shorter coastline when compared to Chile and Peru, mainland Ecuador is likely to house a significant diversity of marine sponges. In part, this will be a consequence of being situated in a convergence zone of two different oceanic currents, the northern warm Panama or El Niño Current, and the southern cold Humboldt or Peru Current (Chavez and Brusca 1991; Fiedler et al. 1992; Glynn 2003). In addition, the presence of varied marine coastal ecosystems, such as mangroves, bays, estuaries, and rocky coasts in this area, also supports this hypothesis. So far, knowledge of the sponge biodiversity of Ecuador is entirely restricted to descriptions of species from the Galapagos Islands (Desqueyroux-Faúndez and van Soest 1997; Bustamante et al. 2002). According to the World Porifera Database (WPD), 87 species have been recorded from these islands (van Soest et al. 2020), both from the shallow waters (Topsent 1895; Wilson 1904; Lendenfeld 1910; de Laubenfels 1939; Lee 1987; Hajdu and Desqueyroux-Faúndez 1994; DesqueyrouxFaúndez and van Soest 1996, 1997; Sarà et al. 2000) and deeper waters (Schuster et al. 2018). Surprisingly, no taxonomic study focused on the sponge diversity of coastal mainland Ecuador, a gap due to a historical lack of baseline scientific initiatives and sponge taxonomists in this region. In order to start reverting this scenario, a national project was funded by the Ecuadorian government aiming at the description of the marine invertebrate biodiversity, and their associated chemical and microbial diversity, in a small marine protected area of the peninsula of Santa Elena, named El Pelado Marine Reserve (REMAPE). The first results of this biodiversity assessment 
have recently been published with a focus on zoantharians (Jaramillo et al. 2018), and sponges come next, also selected for their known content of metabolites with potential pharmacological use (Carroll et al. 2019). The goal of the present study was therefore to describe the most abundant species of sponges occurring in the El Pelado MPA. Herein, we present three new records of Demospongiae for this area, including one new species.

\section{Materials and methods}

\section{Biological material}

Specimens were collected using SCUBA diving in different sites of the El Pelado Marine Reserve (REMAPE - Santa Elena, Ecuador, -80.8221, -1.9228) and photographed in situ (Fig. 1). Samples were preserved in $95 \% \mathrm{EtOH}$ and a voucher sample of each species is deposited at the scientific reference collection of Centro Nacional de Acuicultura e Investigaciones Marinas (CENAIM), with some fragments shared with the sponge collections at Museu Nacional do Rio de Janeiro (MNRJ)/Universidade Federal do Rio de Janeiro (UFRJ, Rio de Janeiro, Brazil).

\section{Morphological examination}

Species identification and morphological descriptions were achieved from ethanol samples and in situ observations. Descriptions were based on dissociated spicules and thick anatomical sections obtained for each specimen following standard protocols outlined in

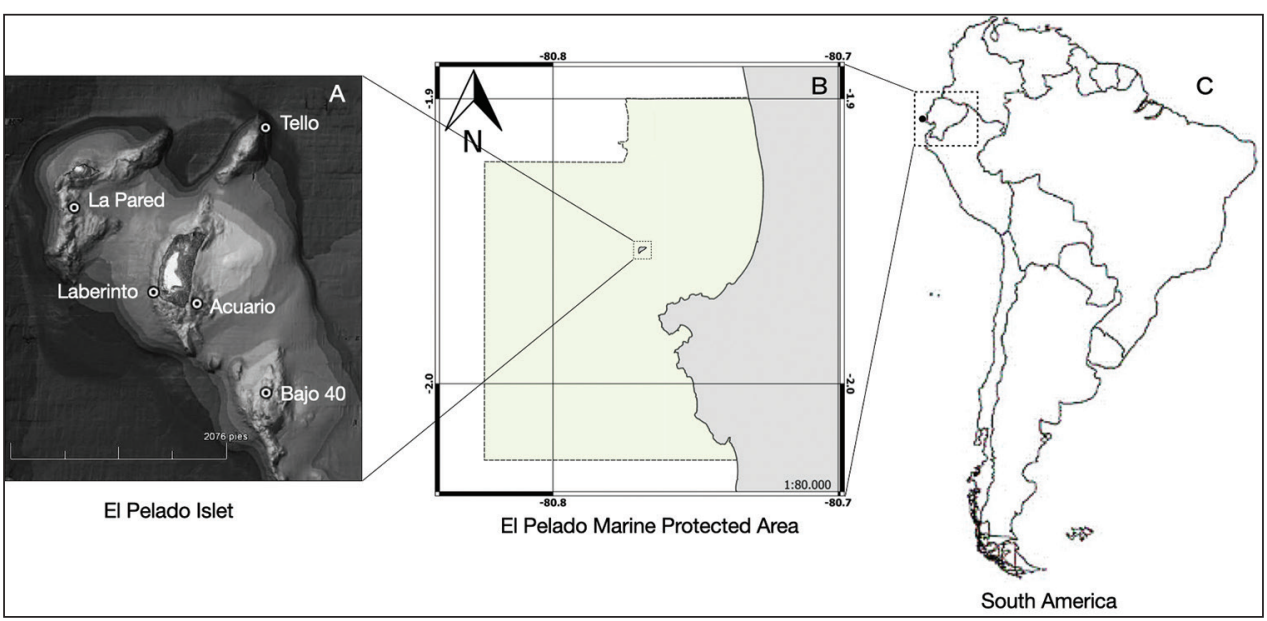

Figure I. Map of the Marine Protected Area El Pelado A The Pelado islet and its submarine platform with five sampling locations of the sponges B map of the whole Marine Protected Area El Pelado at the Ecuadorian coast $\mathbf{C}$ map of South America highlighting Ecuador ( map created using QGIS software Version 3.2). 
Hajdu et al. (2011). Dissociated spicules and thick sections slides were examined under an EVOS Digital Colour Fluorescence Microscope. For each spicule category, at least 20 measurements were made. Metrical data are given in micrometres, unless otherwise indicated, as the range, with the mean and the number of measurements taken (n) in parentheses. The Scanning Electron Microscopes (SEMs) used to obtain the spicule electron micrographs were a JEOL 6390LV at Museu Nacional (UFRJ), and a Hitachi S-4700 SEM at National University of Ireland, Galway. The classification adopted here is that of the 'Systema Porifera' (Hooper and van Soest 2002), as modified by Morrow and Cárdenas (2015), and implemented in the World Porifera Database (van Soest et al. 2020).

\section{Results}

\section{Systematics}

\section{Phylum Porifera Grant, 1835}

Class Demospongiae Sollas, 1885

Subclass Heteroscleromorpha Cárdenas, Pérez \& Boury-Esnault, 2012

Order Poecilosclerida Topsent, 1928

Family Tedaniidae Ridley \& Dendy, 1886

Genus Tedania Gray, 1867

Subgenus Tedania Gray, 1867 sensu Aguilar-Camacho et al. (2018)

\section{Tedania (Tedania) ecuadoriensis Jaramillo \& Hajdu, sp. nov.} http://zoobank.org/05C00AF3-E75C-402E-AAA1-2D511771ADEF Figure 2A-I

Diagnosis. Tedania (Tedania) with rather small ectosomal tylotes $(139-185 \mu \mathrm{m})$, and choanosomal styles $(127-183 \mu \mathrm{m})$, as well as possessing two size categories of onychaetes $(71-133$ and $29-69 \mu \mathrm{m})$.

Etymology. Named after the country where its type locality is situated.

Type material. Holotype: CENAIM 150813EP01-05 with fragment as MNRJ 19918, El Pelado Islet ('La Pared', -1.932847; -80.792453), REMAPE, Santa Elena, Ecuador, 13 $m$ deep, collected by O. Thomas, 13 Aug. 2015. Paratype: CENAIM 150825EP04-05 with fragment as MNRJ 19923, El Pelado Islet ('Laberinto', -1.9355; -80.7896), REMAPE, Santa Elena, Ecuador, 5 m deep, collected by K. Jaramillo, 25 Aug. 2015.

Habit (Fig. 2A). Thickly encrusting to massive (thickness: $0.3 \mathrm{~cm}$ ). The holotype is fragmented, and the largest piece measures $0.8 \times 0.4 \mathrm{~cm}$. Oscula located at the top of short elevations. Consistency soft and compressible. Texture smooth. Colour in life is orange, and in ethanol it turns to violet with some red spots on the surface.

Skeleton (Fig. 2B). Ectosomal architecture with brushes of tylotes, some of which pierce the surface, not easily detachable from the choanosome. Choanosomal architecture a dense, confused reticulation of styles and scattered onychaetes. 

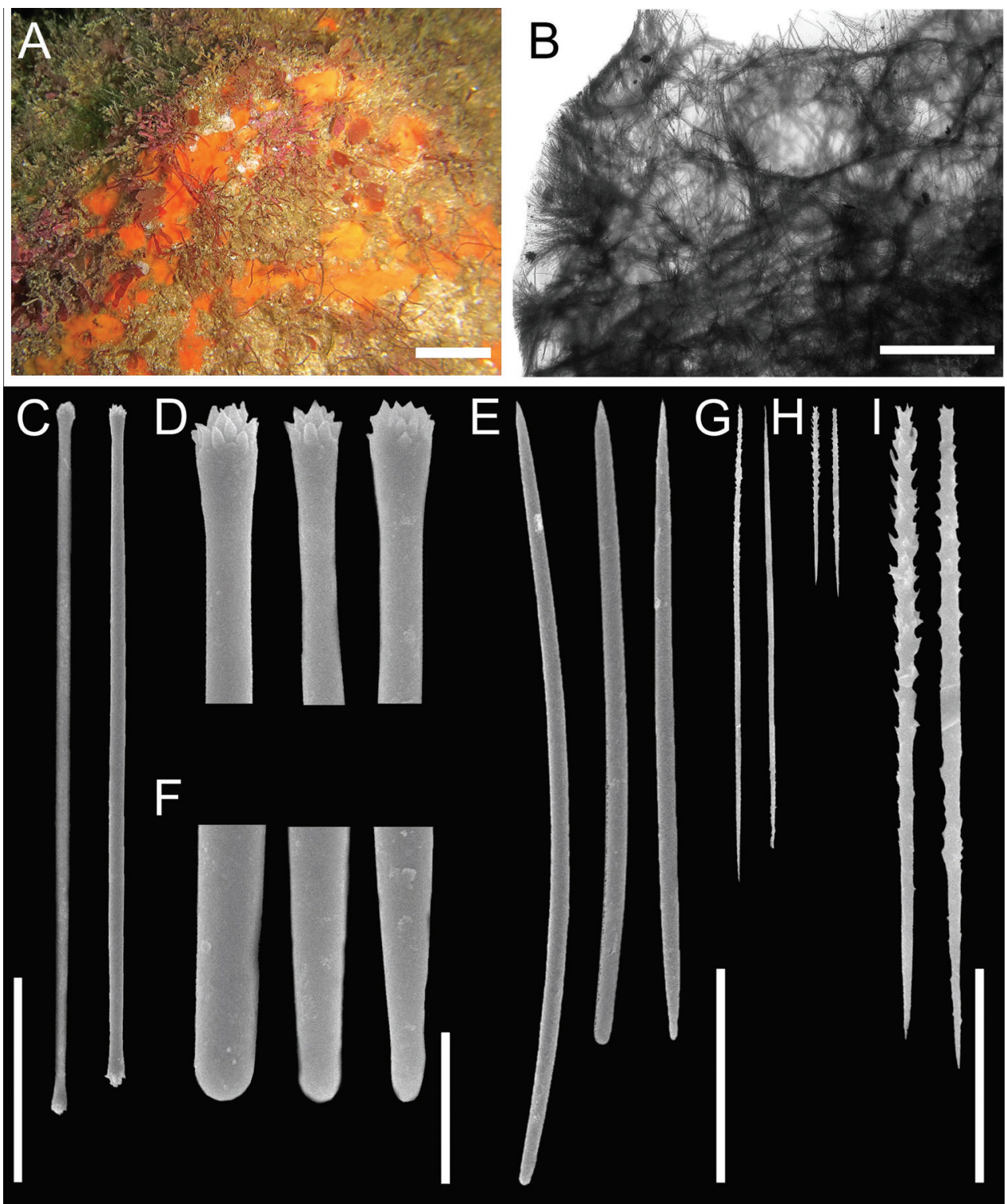

Figure 2. Tedania (Tedania) ecuadoriensis sp. nov. A holotype in situ (CENAIM 150813EP01-05) B transverse section of ectosomal and choanosomal skeletal architecture $\mathbf{C}$ ectosomal tylotes $\mathbf{D}$ detail of terminally microspined terminations of ectosomal tylotes $\mathbf{E}$ choanosomal styles $\mathbf{F}$ detail of the bases of choanosomal styles $\mathbf{G}$ large onychaetes $\mathbf{H}-\mathbf{I}$ small onychaetes. Scale-bars: $2 \mathrm{~cm}(\mathbf{A}) ; 500 \mu \mathrm{m}(\mathbf{B}) ; 50 \mu \mathrm{m}$ (C, E, G-H); $10 \mu \mathrm{m}(\mathbf{D}, \mathbf{F}, \mathbf{I})$.

Spicules. Megascleres (Fig. 2C-F, Table 1): Ectosomal tylotes, 139-85 (168; $\mathrm{n}=30)$; choanosomal styles, 127-183 (155; $\mathrm{n}=35)$. Microscleres (Fig. 2G-I): larger onychaetes, 71-133 (92; $\mathrm{n}=41)$; smaller onychaetes, $29-69(41 ; \mathrm{n}=25)$. 
Table I. Morphology of spicules, locality and depth, for East Pacific Tedania spp. seemingly closer to $T$. (T.) ecuadoriensis sp. nov., and T. ignis. Spicule morphometrics are in micrometres as range with the mean in parentheses, n.r. is not reported.

\begin{tabular}{|c|c|c|c|c|}
\hline Species & Tylotes & Styles & Onychaetes & Locality / depth \\
\hline T. ecuadoriensis sp. nov. & $139-185(168) \times 1.9-3.6(2.4)$ & $127-183(155) \times 2.1-5.5(3.8)$ & $\begin{array}{l}\text { I, 71-133(92) } \\
\text { II, 29-69(41) }\end{array}$ & $\begin{array}{c}\text { El Pelado Islet / } \\
5-13 \mathrm{~m}\end{array}$ \\
\hline $\begin{array}{l}\text { T. fulvum (Aguilar- } \\
\text { Camacho et al., 2018) } \\
\text { (orig. descr.) }\end{array}$ & $130-150(142.5) \times 2.5-5(2.7)$ & $135-185(171.5) \times 2.5-5(3.4)$ & $30-120(60.5) \times 0.5-1$ & $\begin{array}{c}\text { Mexican Pacific } \\
/ 8 \mathrm{~m}\end{array}$ \\
\hline $\begin{array}{l}\text { T. galapagensis } \\
\text { (Desqueyroux-Faúndez } \\
\text { \& van Soest, 1996) } \\
\text { (orig. descr.) }\end{array}$ & $179-234(198) \times 3$ & $192-246(226) \times 6$ & $\begin{array}{l}\text { I, } 173-205(188) \times 2 \\
\text { II, } 61-93(78) \times 0.5-1\end{array}$ & $\begin{array}{c}\text { Galapagos / } \\
78 \mathrm{~m}\end{array}$ \\
\hline $\begin{array}{l}\text { T. obscurata }(\mathrm{de} \\
\text { Laubenfels, 1930) } \\
\text { (orig. descr.) }\end{array}$ & $200-300 \times 6-12$ & present, but rare & $\begin{array}{c}\text { I, n.r. } \\
\text { II, } 80 \times 2\end{array}$ & $\begin{array}{c}\text { California / } \\
\text { intertidal }\end{array}$ \\
\hline $\begin{array}{l}\text { T. tepitootehenuaensis } \\
\text { (Desqueyroux-Faúndez, } \\
\text { 1990)(orig. descr.) }\end{array}$ & $192-250(227) \times 3-7(5)$ & $204-272(241) \times 4-9(7)$ & $\begin{array}{c}\text { I, } 160-285(188) \times 2-3(2) \\
\text { II, } 48-76(59) \times 0.5-0.9(0.6)\end{array}$ & Easter Isl. / $3 \mathrm{~m}$ \\
\hline $\begin{array}{l}\text { T. topsenti (de } \\
\text { Laubenfels, 1930) } \\
\text { (orig. descr.) }\end{array}$ & $200 \times 8$ & $250 \times 11$ & $\begin{array}{l}\text { I (?), } 180 \times 2 \text { reported as "? } \\
\text { raphides", and suggested must } \\
\text { be young megascleres instead }\end{array}$ & $\begin{array}{l}\text { California / } \\
\text { intertidal }\end{array}$ \\
\hline $\begin{array}{l}\text { T. toxicalis (de } \\
\text { Laubenfels, 1930) } \\
\text { (orig. descr.) }\end{array}$ & $200 \times 8-14$ & $100-200 \times 2-7$ & $\begin{array}{c}\text { I, } 150 \\
\text { II, "not observed" }\end{array}$ & $\begin{array}{c}\text { California / } \\
\text { intertidal }\end{array}$ \\
\hline $\begin{array}{l}\text { T. tropicalis (Aguilar- } \\
\text { Camacho et al., 2018) } \\
\text { (orig. descr.) }\end{array}$ & $150-210 \times 2.5-5$ & $150-215 \times 2.5-7.5$ & I, $90-180 \times 0.5-1.8$ & $\begin{array}{c}\text { Mexican Pacific } \\
/ 1-5 \mathrm{~m}\end{array}$ \\
\hline $\begin{array}{l}\text { T. ignis (Duchassaing } \\
\text { \& Michelotti, 1864) } \\
\text { sensu Zea (1987) }\end{array}$ & $181-242(220.4) \times 3-6(4.3)$ & $228-313(259.8) \times 3-8(4.3)$ & $\begin{array}{l}\text { I, } 142-280(230.7) \times 1-3(1.9) \\
\text { II, } 52-138(83.3) \times 0.5-2(1.2)\end{array}$ & $\begin{array}{c}\text { Tropical W } \\
\text { Atlantic / 0-3 m }\end{array}$ \\
\hline
\end{tabular}

Ecology and distribution. The species was found between 5-13 m depth, close to red algae, and slightly covered with sediment. No dermatitis reaction was observed after contact with bare skin.

Remarks. Six species of Tedania were described from the Tropical Eastern Pacific (de Laubenfels 1930; Desqueyroux-Faúndez 1990; Desqueyroux-Faúndez and van Soest 1996; Desqueyroux-Faúndez and van Soest 1997; Aguilar-Camacho et al. 2018), namely T. fulvum Aguilar-Camacho, Carballo \& Cruz-Barraza, 2018; T. galapagensis Desqueyroux-Faúndez \& van Soest, 1996; T. obscurata (de Laubenfels, 1930); T. tepitootehenuaensis Desqueyroux-Faúndez, 1990; T. topsenti de Laubenfels, 1930; T. toxicalis de Laubenfels, 1930 and T. tropicalis Aguilar-Camacho, Carballo \& CruzBarraza, 2018. Tedania galapagensis was an obvious first hypothesis for the identification of the El Pelado Tedania, for its occurrence in the relatively nearby Galapagos Archipelago, but we found it to be distinct from the new species by its tylotes, styles and onychaetes, with much larger dimensions than observed in our new species. When variation of this sort occurs intraspecifically, it is the continental specimen to harbour the largest spicules, as a consequence of likely increased levels of dissolved silica in comparison to oceanic locations (for a discussion in the context of the Caribbean, see Zea (1987). Furthermore, T. galapagensis was reported from deeper waters $(78 \mathrm{~m})$ than those where T. ecuadoriensis sp. nov. was found $(5-13 \mathrm{~m})$. The species appearing closest to our material, as far as spicule micrometrics go, is the Mexican T. fulvum, that also 
has a set of relatively small spicules. The onychaetes, reported in a single, variable sizecategory, match nearly perfectly the full range observed in both categories combined of the new species. On the other hand, the coelosphaerid/hymedesmiid-kind of ectosomal tylote, with smooth, pronounced, elliptical heads, finds no match in the new species, and is seen here as decisive evidence of the non-conspecificity of both species.

Tedania ecuadoriensis sp. nov. with its short tylotes $(168 \mu \mathrm{m}$, mean length) and styles (155 $\mu \mathrm{m}$, mean length) is distinct from all known (sub)Tropical Eastern Pacific Tedania spp. which have these around $200 \mu \mathrm{m}$ or bigger. Tedania ignis, a Tropical Western Atlantic species with considerable overall similarity to the new species proposed, also bears much larger megascleres and microscleres, which contradicts any hypothesis of possible conspecificity.

\section{Order Clionaida Morrow \& Cárdenas, 2015 \\ Family Clionaidae d'Orbigny, 1851 \\ Genus Cliona Grant, 1826}

\section{Cliona aff. euryphylle Topsent, 1888}

Figure 3A-E

Material examined. CENAIM: 160510EP07-01, El Pelado Islet ('Bajo 40', -1.938217; -80.786669), REMAPE, Santa Elena, Ecuador, $12 \mathrm{~m}$ deep, collected by K. Jaramillo, 10 May 2016.

Habit (Fig. 3A, B). Encrusting alpha stage over $15 \times 15 \mathrm{~cm}$ in area. Extended papillae with slightly elevated (up to $5 \mathrm{~mm}$ ) oscula, up to $2 \mathrm{~mm}$ in diameter. Sponges form small patches, with a firm texture, even after removal from substrate. The colour in life is orange, turning to pale yellow in ethanol.

Skeleton. Typical Cliona arrangement, with an ectosomal palisade of tylostyles, and the same spicules in a confused arrangement in the choanosome. Small spirasters are scarce in the papillae, but they occur abundantly dispersed in the choanosome.

Spicules. Megascleres (Fig. 3C-E, Table 2). Tylostyles, 221-336 (267; n = 34) $\times 5-11(7, \mathrm{n}=30)$, with pronounced rounded to oval heads. Microscleres (Fig. 3F). Small and robust spirasters $8-35(19 ; \mathrm{n}=32) \times 3-8(5 ; \mathrm{n}=27)$, with several large conical spines spiralling around the shaft, in helical and S-shaped forms; occasionally approaching amphiasters morphology.

Ecology and distribution. Occurs from 5 to $10 \mathrm{~m}$ depth, over rocks, excavating shells, near red and brown algae, and slightly surrounded with sediment. Cliona euryphylle Topsent, 1888 was originally described from the Atlantic Ocean (Gulf of Mexico) by Topsent (1888), followed by a series of records from the Pacific: de Laubenfels (1954) in the Central Pacific, Bergquist (1968) in New Zealand; Carballo et al. (2004); Carballo et al. (2008); Vega (2012) in the Mexican Pacific; and Pacheco et al. (2018) in the Costa Rican Pacific.

Remarks. Our preliminary results are inconclusive with regard to the identification of this Ecuadorian Cliona material, as no DNA sequence has been published for C. eu- 

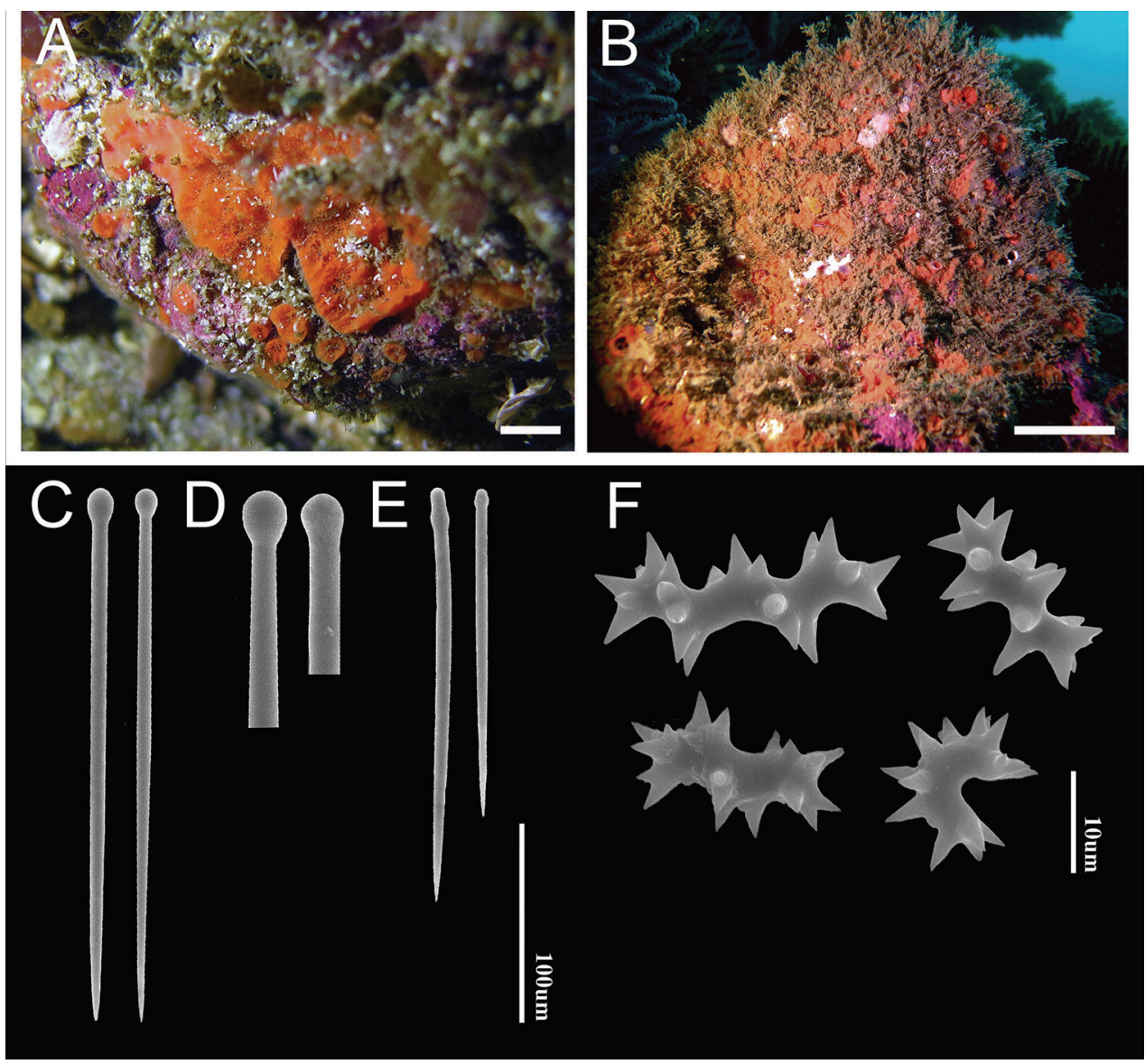

Figure 3. Cliona aff. euryphylle Topsent, 1888 A, B specimen alive in situ (CENAIM 160510EP07-01) collected at El Pelado Marine Reserve $\mathbf{C}$ large tylostyles $\mathbf{D}$ heads of tylostyles $\mathbf{E}$ small tylostyles $\mathbf{F}$ different sizes of spirasters with large spines. Scale-bars: $1 \mathrm{~cm}(\mathbf{A}) ; 5 \mathrm{~cm}(\mathbf{B}) ; 100 \mu \mathrm{m}(\mathbf{C}-\mathbf{E}) ; 10 \mu \mathrm{m}(\mathbf{F})$.

ryphylle, let alone for an Atlantic record of the species. It is also possible that the Ecuadorian species might belong to a distinct species, rather than suppose its crossing of the isthmus through the Panama Canal, as explicitly suggested by Pacheco et al. (2018). Previous records of $C$. euryphylle need to be revised in an integrative approach with more extensive sampling and molecular analyses with higher resolution capabilities.

Meanwhile, we can highlight what these populations share and what distinguishes them from one another in morphological terms. The first, but unlikely, biogeographical record of C. euryphylle is that by de Laubenfels (1954) from Micronesia, perhaps misled by his mistaken interpretation of Topsents' type locality, assumed to be in the Eastern Pacific (Topsent 1888). Even though the proposed transpacific track is unlikely, de Laubenfels' brief description hampers further discussion without re-examining this material. Likely misguided by de Laubenfels' pioneering transpacific range extension, Bergquist (1968) registered the species from New Zealand shallow waters. This is another 
Table 2. Cliona euryphylle Topsent 1888 and Cliona aff. euryphylle: Morphology of spicules, locality and depth for specimens studied here, and from the literature. Species deemed more closely related are included for comparison. Spicule morphometrics are in micrometres as range with the mean in parentheses, n.r. is not reported.

\begin{tabular}{|c|c|c|c|}
\hline Species & Tylotes & Spirasters & Locality / depth \\
\hline C. aff. euryphylle & $\begin{array}{l}\text { I, 221-336 (267) × 5-11(7); } \\
\text { II, 115-264 (211) ×5-9(7) }\end{array}$ & $8-35(19) \times 3-8(5)$ & El Pelado Islet / 5-10 m \\
\hline $\begin{array}{l}\text { C. euryphylle (Topsent, 1888) } \\
\text { (orig. descr.) }\end{array}$ & $300 \times 5$ & $35 \times 5$ & Southern Gulf of Mexico \\
\hline sensu de Laubenfels (1954) & $300 \times 7$ & n.r. $\times 4-8$ & Micronesia / $5 \mathrm{~m}$ \\
\hline sensu Bergquist (1968) & $290-392(344) \times 9.5-17.5(12.5)$ & $7-28(24) \times 0.9-9.2(6.3)$ & New Zealand / 25 m \\
\hline sensu Carballo et al. (2004) & $180-367.5(277) \times 2.5-10(5.5)$ & $10-30(18.1)$ & Mexican Pacific / 4-20 m \\
\hline sensu Vega (2012) & $111-365 \times 1.3-11$ & $30-6$ & Mexican Pacific / 0-3 m \\
\hline sensu Pacheco et al. (2018) & $120-300(201) \times 5-8(6.7)$ & $9-24(18) \times 2-7(4.7)$ & Costa Rica Pacific / 4-20 m \\
\hline $\begin{array}{l}\text { C. aethiopicus (Burton, 1932) (orig. } \\
\text { descr.) }\end{array}$ & $260 \times 7$ & 28 & Gulf of Guinea / 18-30 m \\
\hline C. burtoni (Topsent, 1932) (orig. descr.) & $225-330(175) \times 7-12(2.5)$ & $15-28(40) \times 5-6(1.5)$ & Mediterranean / N/A \\
\hline sensu Bertolino et al. (2013) & $132-287(225) \times 5-7.5(6)$ & $10-45(26.5) \times 1.3-17.5(10)$ & Mediterranean / $30 \mathrm{~m}$ \\
\hline $\begin{array}{l}\text { C. caledoniae (van Soest \& Beglinger, } \\
2009 \text { ) (orig. descr.) }\end{array}$ & $246-426(360.9) \times 8-12(9.8)$ & $19-31(24.3) \times 5-9(6.8)$ & NE Atlantic / 82-131 m \\
\hline $\begin{array}{l}\text { C. dioryssa (de Laubenfels, 1950); } \\
\text { sensu Rützler (1974) }\end{array}$ & $107-392(244.4) \times 3.7-7.4(5.4)$ & $\begin{array}{l}\text { I, } 11-42(27.4) \times 1.4-4.8(3.2)(\text { shaft }) ; \\
\text { II, } 19-43(33.9) \times 0.6-2.2(1.5)(\text { shaft })\end{array}$ & Bermuda / 0-12 m \\
\hline sensu Muricy and Hajdu (2006) & $200-440$ & $\begin{array}{l}\text { I, } 25-40 \\
\text { II, } 10-20\end{array}$ & SE and NE Brazil / 5-25 m \\
\hline
\end{tabular}

unlikely record simply from its distance from previous localities. Furthermore, Bergquist offered some observations that might be interpreted to be suggestive of non-conspecificity, such as the larger dimensions of megascleres (up to $392 \mu \mathrm{m}$ ), and the abundance of microscleres. The tylostyles in the specimens described by Bergquist (1968) were reported to reach $17.5 \mu \mathrm{m}$ in thickness, while Topsent's original data indicates $5 \mu \mathrm{m}$. The same applies to the thickness of the spirasters in Bergquist's specimens $(\leq 9 \mu \mathrm{m}$ thick, or $\leq 14 \mu \mathrm{m}$, if spines are included), while Topsent mentioned a thickness of $5 \mu \mathrm{m}$. These differences indicate that these populations do not belong to the same species.

However, a series of records exists that have been considered indicative of the species' transisthmian distribution (Carballo et al. 2004; Vega 2012; Pacheco et al. 2018). These report on sponges bearing tylostyles up to $368 \mu \mathrm{m}$ long, and $11 \mu \mathrm{m}$ thick (Carballo et al. 2004; Vega 2012) respectively, but also, in the case of Pacific Costa Rican specimens, only up to $300 \times 8 \mu \mathrm{m}$ (Pacheco et al. 2018), which considerably approach values originally reported by Topsent. On the other hand, spirasters appear to fall short from those of Topsent, up to nearly $50 \%$ longer. While the possibility cannot be discarded that these amphi-American populations belong to the same species, this should be verified by an alternative dataset, as suggested above.

Cliona aff. euryphylle shares the same spicules (thick and short spirasters) with four other Cliona spp., namely C. aethiopicus Burton, 1932, C. burtoni Topsent, 1932, C. caledoniae van Soest \& Beglinger, 2009 and C. dioryssa (de Laubenfels, 1950). However, these species have unusual aspects of their spirasters, both in dimensions as well as outline, which suggest closer proximity between the Ecuadorian species and C. euryphylle. Cliona aethiopicus was considered closely allied to C. chilensis by Burton (1932), 
irrespective of Thiele's (1905) hesitation regarding the origin of a few spirasters found in the encrusting Chilean specimen he studied. The presence of these spirasters in the type material of $C$. chilensis was not confirmed by Desqueyroux-Faúndez and van Soest (1997), which establishes both species' spicule sets as markedly divergent. The former, with abundant microscleres. The latter, devoid of those. Contrastingly to what we have observed in the Ecuadorian C. aff. euryphylle, with varied microsclere morphologies, Burton (1932) did not mention any variation in the spirasters of $C$. aethiopicus.

Cliona burtoni has spirasters with proportionately much shorter spines, and much straighter axes when compared to the pattern seen in $C$. aff. euryphylle. Furthermore, the tylostyles with predominantly subterminal heads present in C. burtoni, are only occasionally present in the latter species. Cliona caledoniae has spirasters bearing extremely stout and somewhat obtuse spines that differ considerably from the pointier spines seen in $C$. aff. euryphylle. Finally, $C$. dioryssa's tylostyles approach $400 \mu \mathrm{m}$, and the species has two categories of spirasters of rather varied morphology, reaching over $40 \mu \mathrm{m}$ in length, also appearing distinct from those in C. aff. euryphylle.

\section{Order Haplosclerida Topsent, 1928 \\ Family Callyspongiidae de Laubenfels, 1936 \\ Genus Callyspongia Duchassaing \& Michelotti, 1864}

\section{Subgenus Callyspongia Duchassaing \& Michelotti, 1864}

Diagnosis. Callyspongia with smooth surface, ectosomal skeleton not echinated, spongin sheath conspicuous, no fibrofascicles. Modified from (Desqueyroux-Faúndez and Valentine 2002).

Remarks. The emphasis by Desqueyroux-Faúndez and Valentine (2002) on a single size of ectosomal mesh of "regular size of single, rounded to polygonal mesh", in their own words was misleading, as a hierarchical pattern of smaller meshes within larger meshes is apparent in several morphological descriptions of the type species, $C$. fallax (Duchassaing \& Michelotti, 1864), such as those by van Soest (1980) and Zea (1987).

\section{Identification key to the subgenera of Callyspongia}

Ectosomal echination by a strong palisade of spicule brushes; narrow spongin sheath on primary multi-spicular choanosomal fibres

Cavochalina

- $\quad$ Ectosomal echination by free spicules; large spongin sheath on primary paucispicular choanosomal fibres Euplacella Surface smooth; spongin sheath conspicuous Callyspongia

- $\quad$ Surface conulose to spiny; spongin sheath only seldom conspicuous, mostly meagre or absent 


\section{Callyspongia (Callyspongia) aff. californica Dickinson, 1945}

sensu Cruz-Barraza and Carballo (2008)

Figure $4 \mathrm{~A}-\mathrm{H}$

Callyspongia cf. californica - Calabro et al. 2018: supp. inf., P3.

Material examined. CENAIM 150820EP02-01 with fragment as MNRJ 19920, 'Acuario', El Pelado Islet, REMAPE, Santa Elena, Ecuador (-1.936167; -80.788922), 6 m deep, collected by K. Jaramillo, 20 Aug. 2015. CENAIM 150813EP07-07 or MNRJ 19924, 'Bajo 40', El Pelado Islet, REMAPE, Santa Elena, Ecuador (-1.938217; -80.786669), $15 \mathrm{~m}$ deep, collected by O. Thomas, 13 Aug. 2015. CENAIM 150825EP04-04 or MNRJ 19925, 'Laberinto', El Pelado Islet, REMAPE, Santa Elena, Ecuador (-1.9355; -80.7896), $5 \mathrm{~m}$ deep, collected by K. Jaramillo, 25 Aug. 2015 [voucher from Calabro et al. 2018]. CENAIM 160213EP04-01 or MNRJ 19949 and CENAIM 160213EP0402 or MNRJ 19951, 'Laberinto', El Pelado Islet, REMAPE, Santa Elena, Ecuador (-1.9355; -80.7896), 5-7 m deep, collected by O. Thomas, 13 Feb. 2016.

Material studied for comparison. C. californica, voucher number: IRCSET364 from Parque de la Reina Acapulco, Acapulco, México (16.8491314; -99.9015755), 4-15 m deep, collected by J.L. Carballo, 01 Jul. 2012. Molecular Evolution and Systematics (MEAS) collection at National University of Ireland, Galway (NUIG).

Habit (Fig. 4A-C). Cushion-shaped, usually up to $2-3 \mathrm{~cm}$ thick only, frequently bearing short irregularly cylindrical or volcano-shaped projections topped by roundish oscula, $1-5 \mathrm{~mm}$ in diameter. Occasionally, larger coalescent tubes with apical oscula (over $1 \mathrm{~cm}$ in diameter) can also be seen. Consistency soft, easily torn, yielding moderate amounts of mucus upon collection and handling. Texture smooth. Colour in life ranging from white to blueish/purplish, becoming beige in ethanol.

Skeleton (Fig. 4D-F). Ectosomal architecture a neat reticulation of polygonal primary and secondary meshes, the former outlined by pauci- to multi-spicular fibres, the latter by thin very slender fibres, mostly one or two spicules across, and a single spicule long. Choanosomal architecture an irregular polygonal reticulation of pauci- to multispicular fibres, frequently sinuous.

Spicules (Fig. 4G-H, Table 3). Oxeas in a single size category, slender, slightly irregular, mostly slightly curved or bent in the middle, mostly with slightly roundish, irregular ends, $46-83(57, \mathrm{n}=31) \times 1.2-5.0 \mu \mathrm{m}(2.5, \mathrm{n}=28)$.

Ecology and distribution. The sponge is quite abundant in the shallow waters at El Pelado and in the nearby continental shore, where it occurs in areas of considerable water flush, frequently in close association with Pocillopora (Lamarck, 1816) corals and many species of octocorals. Red algal turfs are frequently seen as epibionts. Callyspongia aff. californica also presents a complete family of bioactive amphiphilic compounds named callyspongidic acids that have inhibitory properties against the melanoma cell line A2058, metabolites that could be important for further chemotaxonomy studies (Calabro et al. 2018). Its recorded depth at El Pelado is 5-20 m, but its frequent finding beached after storms suggests its occurrence in even shallower waters. This might be the southernmost record of C. californica (sensu Cruz-Barraza 

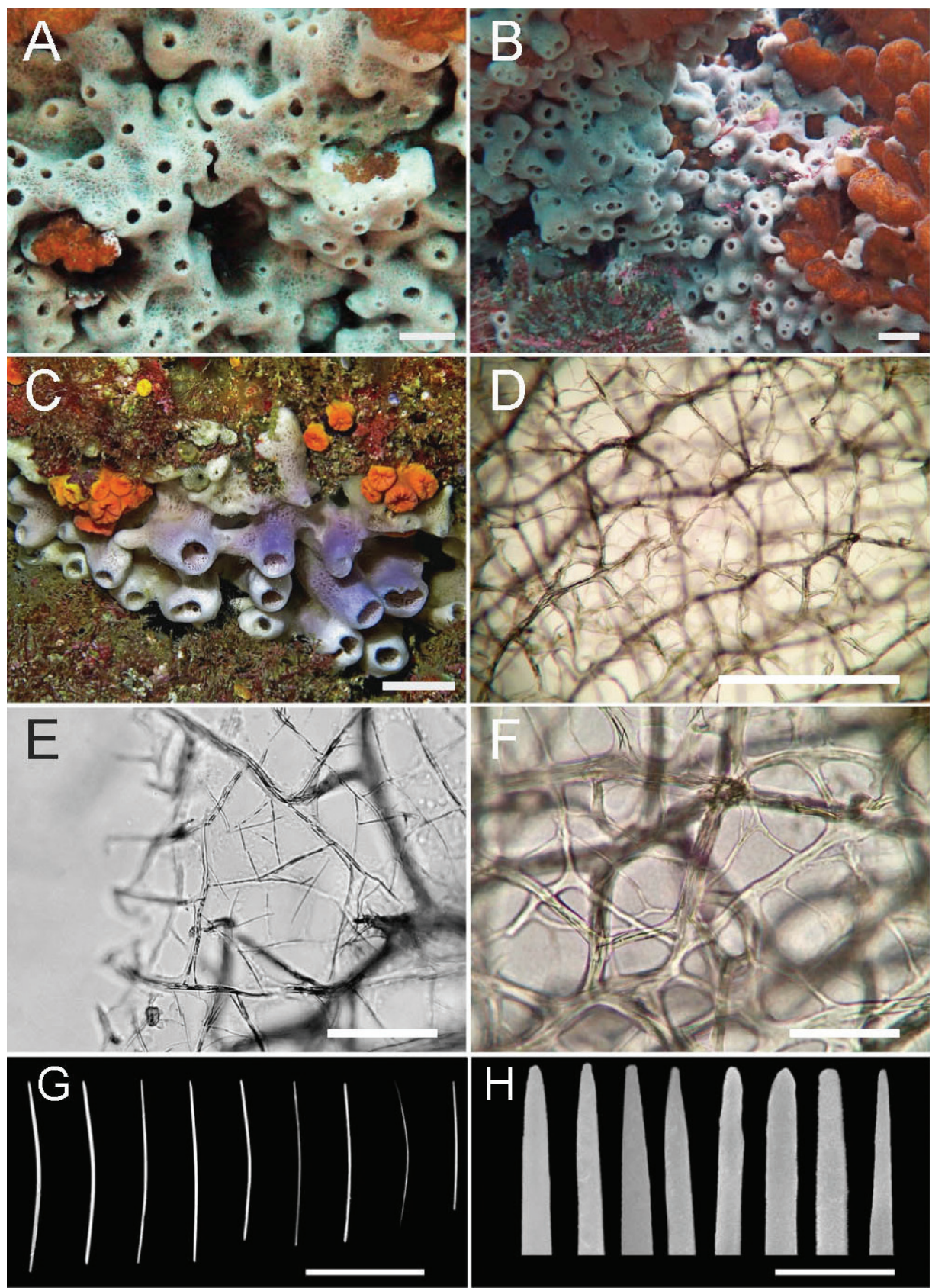

Figure 4. Callyspongia (Callyspongia) aff. californica Dickinson, 1945 (sensu Cruz-Barraza and Carballo 2008) A-C specimens alive in situ: A CENAIM 150820EP02-01 B CENAIM 150813EP07-07 C specimen collected for chemical studies CENAIM 150825EP04-04, of the rarer tubular morphotype D delicate ectosomal reticulation seen through stouter subectosomal polygonal meshes $\mathbf{E}$ detail of ectosomal reticulation with primary and secondary meshes $\mathbf{F}$ detail of subectosomal reticulation showing stouter, multi-spicular tracts $\mathbf{G}$ oxeas $\mathbf{H}$ details of the terminations of the oxeas. Scale bars: $1.5 \mathrm{~cm}(\mathbf{A}-\mathbf{C})$; $1000 \mu \mathrm{m}(\mathbf{D}) ; 400 \mu \mathrm{m}(\mathbf{E}-\mathbf{F}) ; 50 \mu \mathrm{m}(\mathbf{G}) ; 50 \mu \mathrm{m}(\mathbf{H})$. 
Table 3. Callyspongia (C.) californica Dickinson, 1945 and C. (C.) aff. californica: Morphology of spicules spicule (in micrometres), locality and depth for specimens studied here, and from the literature. Spicule morphometrics are in micrometres as range with the mean in parentheses.

\begin{tabular}{lcc}
\hline \multicolumn{1}{c}{ Species } & Oxeas & Locality / depth \\
\hline $\begin{array}{l}\text { C. aff. californica } \\
\text { 150820EP02-01 } \\
\text { (MNRJ 19920) }\end{array}$ & $46-71(57.5)(\mathrm{N}=30)$ & El Pelado Islet / 6 m \\
$\begin{array}{l}\text { 150813EP07-07 } \\
\text { (MNRJ 19924) }\end{array}$ & $48-69(61.2)(\mathrm{N}=30)$ & El Pelado Islet / $15 \mathrm{~m}$ \\
$\begin{array}{l}\text { 150825EP04-04 } \\
\text { (MNRJ 19925) }\end{array}$ & $50-81(67.3)(\mathrm{N}=13)$ & El Pelado Islet / $5 \mathrm{~m}$ \\
$\begin{array}{l}\text { 160213EP04-01 } \\
\text { (MNRJ 19949) }\end{array}$ & $61-74(65.9)(\mathrm{N}=16)$ & El Pelado Islet / $7 \mathrm{~m}$ \\
$\begin{array}{l}\text { 160213EP04-02 } \\
\text { (MNRJ 19951) }\end{array}$ & $50-83(63.9)(\mathrm{N}=06)$ & El Pelado Islet / $5 \mathrm{~m}$ \\
$\begin{array}{l}\text { IRCSET364 } \\
\text { C. californica Dickinson, 1945 (orig. descr.) }\end{array}$ & $56-105(67) \times 1.5-5.0(2.4)$ & Mexican Pacific / $8 \mathrm{~m}$ \\
sensu Sim and Bakus (1986) & $80-150 \times 3-5$ & California / 3.6 m \\
sensu Cruz-Barraza and Carballo (2008) & $84-132(105) \times 2.4-7(5.3)$ & Mexican Pacific / beached \\
\hline
\end{tabular}

and Carballo 2008; non sensu Dickinson, 1945), formerly known only from Mexico (Cruz-Barraza and Carballo 2008) and possibly California (Sim and Bakus 1986), and first time citation to the Tropical South-eastern Pacific (but see the Remarks section). Interestingly, C. californica has also been observed in close association with Pocillopora corals in the Mexican Pacific coast.

Remarks. Callyspongia californica, originally reported from Mexico (Dickinson 1945), has subsequent records from California (Sim and Bakus 1986) and several Mexican locations (Cruz-Barraza and Carballo 2008). Dickinson (1945) highlighted the $150 \mu \mathrm{m}$ long oxeas in his $C$. californica material as the most striking feature separating this species from any other. Sim and Bakus (1986) found oxeas only up to about $130 \mu \mathrm{m}$ in California. Then, Cruz-Barraza and Carballo (2008), in spite of studying nearly topotypical specimens (those from Oaxaca), could not find oxeas larger than $117 \mu \mathrm{m}$. We had access to a comparative sample kindly sent on loan by JL Carballo, obtained from Acapulco (Guerrero), only about $400 \mathrm{~km}$ distant from the type locality at Tangola Island (Oaxaca). While spicule dimensions in the Ecuadorian specimens are even smaller, being $\leq 100 \mu \mathrm{m}$ in the specimens sampled, the ability of $C$. californica to build oxeas of different sizes even in the same locality (JL Carballo pers. comm. 2019) suggests that spicule size is not a useful trait to distinguish the Ecuadorian specimens as a separate species. Despite the observed difference in spicule dimensions, overall morphological and ecological similarity strongly indicate that our specimen from Ecuador is most likely conspecific to the Mexican sample studied.

Calabro et al. (2018) provided a brief description of the Ecuadorian species in their Supporting Information, but the rationale for this name choice is only given here. Had we revised the species' type specimen, and generated sequences for faster evolving markers, we might have been confident of Ecuadorian specimens being best assigned to $C$. californica, despite a Meridional occurrence about 4,000 km distant from the species' previously known geographic range. Unfortunately, the type specimen could not be located and may have been lost/misplaced in the transfer of the Dickinson material 
from the University of Southern California to the Natural History Museum of Los Angeles (K. Omura, pers. comm. May $31^{\text {st }}$, 2019), so we could not attempt to extract DNA from it for comparison. As such, we opted to identify the Ecuadorian species as C. aff. californica instead, for the time being. Whether subsequent Mexican records of C. californica (e.g., Carballo et al. 2004, 2008; Vega 2012) are indeed conspecific with the type specimen of this species, we cannot say. Conservatively, we suggest them being provisionally best referred to as $C$. aff. californica too.

\section{Discussion}

This work represents the first morphological study of sponges off the coast of mainland Ecuador. As a result, we revealed two new records for the Ecuadorian mainland coast, and the South-eastern Pacific, and one new species Tedania ecuadoriensis sp. nov., provisionally endemic of the MPA El Pelado, at the Guayaquil Marine Ecoregion, Tropical Eastern Pacific Realm.

Information and interest in Ecuadorian sponges have increased in recent years as a consequence of the growing body of evidence on the marked underestimation of sponge biodiversity in the whole SE Pacific (e.g., Azevedo et al. 2009, 2015; Hajdu et al. 2013). Increasingly, this renewed interest in the biodiversity inventory of this broad area has been conducted via an integrative approach, by combining classical morphological techniques with an assessment of several molecular markers (De Paula et al. 2012; Azevedo et al. 2015). This will be the way to progress if a sound increase in knowledge on Ecuadorian marine sponges is sought. This is made clear by the partial identifications put forward here for Callyspongia aff. californica and Cliona aff. euryphylle. The final conclusive identification of these species depends on the integration of alternative data sources, which has not been possible here for several reasons: missing type materials, lack of well-preserved topotypical specimens, failure to obtain sequences from the ideal molecular markers, and time constraints.

The hesitant species determination provided here for $C$. aff. euryphylle and $C$. aff. californica derive in the first place from the insufficient data available for the type specimens of both species. The lack of type data meant that despite how similar Ecuadorian data was to more recent comprehensive records of both species, we could not conclusively identify both. Only molecular evidence can confirm these possibly discontinuous distributions, as verified for C. celata Grant, 1826 in the Western Atlantic (De Paula et al. 2012; Gastaldi et al. 2018), or the calcareous sponge Clathrina aurea SoléCava, Klautau, Boury-Esnault, Borojevic \& Thorpe, 1991, formerly endemic to Brazil, but recently recorded from Peru (Azevedo et al. 2015) and the Caribbean (Fontana et al. 2018). Whether subsequent Mexican records of C. californica (e.g., Carballo et al. 2004, 2008; Vega 2012) are indeed conspecific with the type specimen of this species, we cannot say. We feel confident though, that the Ecuadorian specimens are conspecific to these subsequent Mexican records of $C$. californica, all of which we suggest being provisionally best referred to as $C$. aff. californica. 
Despite the value of the integrative approach to systematics to correctly delimit species (e.g., Schlick-Steiner et al. 2010), a conclusive application of characters other than morphological is often impossible for the type materials. Integrative approaches are also hindered by lack of any alternative data for the type species in a genus, or for any other more closely related species, whatsoever. Our efforts to integratively describe the species presented here were unsuccessful. Nevertheless, we argue this is the way to move forward in the taxonomic study of Ecuadorian sponges, and beyond this, we recommend sponge taxonomists to turn integrative taxonomy into routine work, so, as a community, we can build a reference dataset to help determine the true extent of relatedness among sponge lineages.

Ecuador is a rare, if not unique, example of nation where $97 \%$ ( 87 of 90 recorded species) of the knowledge of the poriferan biological resource, mainly composed of Demospongiae, is derived from an offshore location (Schuster et al. 2018, van Soest et al. 2020). Irrespective of the biological importance of the Galapagos Archipelago, this fact needs a major reversal. It is doubtful that there will ever be a proliferation of research institutes in the archipelago that might deepen the study of several aspects of these holobionts, whose transfer to mainland Ecuador is unlikely, at the least. Getting to know more the easily accessible sponges from the coast of mainland Ecuador is essential to develop this scientific field in the country, as highlighted from pioneering bioprospecting conducted at Reserva Marina El Pelado (Calabro et al. 2018).

The rather localized distributional data generated in this study does not permit to establish biogeographic boundaries for marine sponges along the Ecuadorian mainland. These will ultimately depend on expanding the taxonomic inventory to additional localities to the $S$ and N of MPA El Pelado. Nevertheless, present data help filling in an important knowledge gap on the distribution of Tropical Eastern Pacific sponges, by expanding the notoriously underestimated sponge biodiversity inventory into the Guayaquil Ecoregion. It is expected that sponges will produce patterns similar to those recently reported for Ecuadorian zoantharians (Jaramillo et al. 2018), where Panamanian and Humboldtian affinities are clearly evident, indicating species coming from the north, and from the south, respectively. The first of these patterns is apparent for $C$. aff. californica, known all the way up to Mexico, at least. However, species illustrating affinities to the colder South American Pacific, as well as to the Galapagos Islands remain to be spotted on coastal mainland Ecuador marine sponges.

\section{Acknowledgements}

This work was funded by the Secretaría de Educación, Ciencia y Tecnología e Innovación of Ecuador (SENESCYT) in the framework of the PIC-14-CENAIM-001 Project "Caracterización de la Biodiversidad Microbiológica y de Invertebrados de la Reserva Marina "El Pelado" a escalas taxonómica, metabolómica y metagenómica para su uso en Salud Humana y Animal". K.J. acknowledges NUI Galway for supporting part of her Ph.D. scholarship, but also the Project National Marine Biodiscovery Labo- 
ratory through a grant from the Marine Institute PBA/MB/16/01. E.H. is funded by the Brazilian National Council for Scientific and Technological Development (CNPQ), by Coordination of Superior Level Staff Improvement (CAPES), and Carlos Chagas Filho Research Support Foundation (FAPERJ). Authors would like also to thank J.L. Carballo (Universidad Nacional Autónoma de México) for kindly sending the Mexican voucher of $C$. californica; Pierce Lalor (senior technician at NUI-Galway), and Camila Messias and Beatriz C.A. Cordeiro (technicians at Dept. of Invertebrates), who assisted us with the acquisition of SEM images, respectively at the Center for Microscopy and Imaging (CMI) - NUI Galway and the Center for Scanning Electron Microscopy of Museu Nacional/UFRJ; and Kathy Omura (Natural History Museum of Los Angeles) for her efforts in trying to locate the type material of Callyspongia californica.

\section{References}

Aguilar-Camacho JM, Carballo JL, Cruz-Barraza JA (2018) Tedania (Porifera: Demospongiae: Poecilosclerida) from the Mexican Pacific with the description of two new species. Journal of Natural History 52(19-20): 1311-1332. https://doi.org/10.1080/00222933.2018.1462893

Aguirre LK, Hooker Y, Willenz Ph, Hajdu E (2011) A new Clathria (Demospongiae, Microcionidae) from Peru occurring on rocky substrates as well as epibiontic on Eucidaris thouarsii sea urchins. Zootaxa 3085(1): 41-54. https://doi.org/10.11646/zootaxa.3085.1.3

Azevedo F, Condor-Lujan B, Willenz Ph, Hajdu E, Hooker Y, Klautau M (2015) Integrative taxonomy of calcareous sponges (subclass Calcinea) from the Peruvian coast: morphology, molecules, and biogeography. Zoological Journal of the Linnean Society 173(4): 787-817. https://doi.org/10.1111/zoj.12213

Azevedo F, Hajdu E, Willenz Ph, Klautau M (2009) New records of Calcareous sponges (Porifera, Calcarea) from the Chilean coast. Zootaxa 2072(1): 1-30. https://doi.org/10.11646/ zootaxa.2072.1.1

Bell JJ (2007) Contrasting patterns of species and functional composition of coral reef sponge assemblages. Marine Ecology Progress Series 339: 73-81. https://doi.org/10.3354/ meps339073

Bell JJ, Barnes DKA (2003) The importance of competitor identity, morphology and ranking methodology to outcomes in interference competition between sponges. Marine Biology 143: 415-426. https://doi.org/10.1007/s00227-003-1081-0

Bell JJ, Smith D (2004) Ecology of sponge assemblages (Porifera) in the Wakatobi region, south-east Sulawesi, Indonesia: richness and abundance. Journal of the Marine Biological Association of the United Kingdom 84(3): 581-591. https://doi.org/10.1017/ S0025315404009580h

Bergquist PR (1968) The Marine Fauna of New Zealand: Porifera, Demospongiae, Part 1 (Tetractinomorpha and Lithistida). New Zealand Deparment of Scientific and Industrial Research Bulletin 188 - New Zealand Oceanographic Institute Memoir 37: 1-105.

Burton M (1932) Sponges. Discovery Reports 6: 237-392. [pls 48-57] https://doi.org/10.5962/ bhl.part.24379 
Bustamante RH, Vinueza LR, Smith F, Banks S, Calvopiña M, Francisco V, Chiriboga A, Harris J (2002) Comunidades submareales rocosas I: Organismos sésiles y mesoinvertebrados móviles. In: Danulat E, Edgar GJ (Eds) Reserva Marina de Galápagos. Línea Base de Biodiversidad. Fundación Charles Darwin/Servicio Parque Nacional Galápagos, Santa Cruz, Galápagos, 38-67.

Calabro K, Chalen BE, Genta-Jouve G, Jaramillo KB, Dominguez C, de la Cruz M, Cautain B, Reyes F, Thomas OP, Rodriguez J (2018) Callyspongidic acids: Amphiphilic diacids from the tropical Eastern Pacific sponge Callyspongia cf. californica. Journal of Natural Products 81(10): 2301-2305. https://doi.org/10.1021/acs.jnatprod.8b00683

Carballo JL, Bautista-Guerrero E, Leyte-Morales GE (2008) Boring sponges and the modeling of coral reefs in the East Pacific Ocean. Marine Ecology Progress Series 356: 113-122. https://doi.org/10.3354/meps07276

Carballo JL, Cruz-Barraza JA, Gómez P (2004) Taxonomy and description of clionaid sponges (Hadromerida, Clionaidae) from the Pacific Ocean of Mexico. Zoological Journal of the Linnean Society 141(3): 353-397. https://doi.org/10.1111/j.1096-3642.2004.00126.x

Carroll AR, Copp BR, Davis RA, Keyzers RA, Prinsep MR (2019) Marine natural products. Natural Product Reports 36: 122-173. https://doi.org/10.1039/C8NP00092A

Chavez FP, Brusca RC (1991) The Galápagos Islands and their relation to oceanographic processes in the Tropical Pacific. In: James MJ (Ed.) Galápagos Marine Invertebrates: Taxonomy, Biogeography, and Evolution in Darwin's Islands. Springer, Boston, 9-33. https:// doi.org/10.1007/978-1-4899-0646-5_2

Cóndor-Luján B, Azevedo F, Hajdu E, Hooker Y, Willenz Ph, Klautau M (2019) Tropical Eastern Pacific Amphoriscidae Dendy, 1892 (Porifera: Calcarea: Calcaronea: Leucosolenida) from the Peruvian coast. Marine Biodiversity 49: 1813-1830. https://doi.org/10.1007/ s12526-019-00946-y

Costa G, Bavestrello G, Pansini M, Bertolino M (2020) Acanthella danerii sp. nov. (Demospongiae, Bubarida, Dictyonellidae) from Chilean fjords (South Pacific Ocean). Zootaxa, 4790(2): 393-396. https://doi.org/10.11646/zootaxa.4790.2.13

Cruz-Barraza JA, Carballo JL (2008) Taxonomy of sponges (Porifera) associated with corals from the Mexican Pacific Ocean. Zoological Studies 47(6): 741-758. http://zoolstud.sinica.edu.tw/Journals/47.6/741.pdf

de Laubenfels MW (1930) The sponges of California. PhD Thesis, Stanford University, USA. de Laubenfels MW (1939) Sponges collected on the presidential cruise of 1938. Smithsonian Miscellaneous Collections 98(15): 1-7. https://doi.org/10.5962/bhl.part.4785

de Laubenfels MW (1954) The Sponges of the West-Central Pacific. College Press Monographs, Oregon State, 218 pp. https://doi.org/10.5962/bhl.title.6516

De Paula TS, Zilberberg C, Hajdu E, Lôbo-Hajdu G (2012) Morphology and molecules on opposite sides of the diversity gradient: four cryptic species of the Cliona celata (Porifera, Demospongiae) complex in South America revealed by mitochondrial and nuclear markers. Molecular Phylogenetics and Evolution 62: 529-541. https://doi.org/10.1016/j. ympev.2011.11.001

de Voogd NJ, Becking LE, Hoeksema BW, Noor A, van Soest RWM (2004) Sponge interactions with spatial competitors in the Spermonde Archipielago. In: Pansini M, Pronzato R, 
Bavestrello G, Manconi R, Sarà M (Eds) Sponge Science in the New Millenium. Bolletino dei Musei e degli Instituti Biologici dell'Universitá di Genova 68: 253-261.

Desqueyroux-Faúndez R (1990) Spongiaires (Demospongiae) de l'Ile de Pâques (Isla de Pascua). Revue Suisse de Zoologie 97: 373-409. https://doi.org/10.5962/bhl.part.79743

Desqueyroux-Faúndez R, Valentine C (2002) Family Callyspongiidae de Laubenfels, 1936. In: Hopper JNA, van Soest RWM, Willenz Ph (Eds) Systema Porifera. Springer, Boston, 835-851. https://doi.org/10.1007/978-1-4615-0747-5_90

Desqueyroux-Faúndez R, van Soest RWM (1996) A review of Iophonidae, Myxillidae and Tedaniidae occurring in the south east Pacific (Porifera: Poecilosclerida). Revue suisse de Zoologie 103: 3-80. https://doi.org/10.5962/bhl.part.79938

Desqueyroux-Faúndez R, van Soest RWM (1997) Shallow-water Demosponges of the Galapagos Islands. Revue Suisse de Zoologie 104: 379-467. https://doi.org/10.5962/bhl.part.80003

Dickinson MG (1945) Sponges of the Gulf of California. In: Reports on the collections obtained by Alan Hancock Pacific Expeditions of Velero III off the coast of Mexico, Central America, South America, and Galapagos Islands in 1932, in 1933, in 1934, in 1935, in 1936, in 1937, in 1939, and 1940. The University of Southern California Press, Los Angeles, 55 pp. [pls 1-97]

Fernandez JCC, Cárdenas CA, Bravo A, Lôbo-Hajdu G, Willenz Ph, Hajdu E (2016) Lissodendoryx (Ectyodoryx) Lundbeck, 1909 (Coelosphaeridae, Poecilosclerida, Demospongiae) from Southern Chile: new species and a discussion of morphologic characters in the subgenus. Zootaxa 4092(1): 69-89. https://doi.org/10.11646/zootaxa.4092.1.4

Fiedler PC, Chavez FP, Behringer DW, Reilly SB (1992) Physical and biological effects of Los Niños in the eastern tropical Pacific, 1986-1989. Deep Sea Research Part A. Oceanographic Research Papers 39(2): 199-219. https://doi.org/10.1016/0198-0149(92)90105-3

Fontana T, Cóndor-Luján B, Azevedo F, Pérez T, Klautau M (2018) Diversity and distribution patterns of Calcareous sponges (subclass Calcinea) from Martinique. Zootaxa 4410(2): 331-369. https://doi.org/10.11646/zootaxa.4410.2.5

Gastaldi M, De Paula TS, Narvarte MA, Lôbo-Hajdu G, Hajdu E (2018) Marine sponges (Porifera) from the Bahía San Antonio (North Patagonian Gulfs, Argentina), with additions to the phylogeography of the widely distributed Cliona aff. celata and Hymeniacidon perlevis, and the description of two new species. Marine Biology Research 14(7): 682-716. https:// doi.org/10.1080/17451000.2018.1506136

Glynn PW (2003) Coral communities and coral reefs of Ecuador. In: Cortés J (Ed.) Latin American Coral Reefs. Elsevier Science B.V., Amsterdam, 449-472. https://doi.org/10.1016/ B978-044451388-5/50020-5

Hajdu E, Desqueyroux-Faúndez R (1994) A synopsis of South American Mycale (Mycale) (Poecilosclerida, Demospongiae), with description of three new species and a cladistic analysis of Mycalidae. Revue Suisse de Zoologie 101: 563-600. https://doi.org/10.5962/bhl. part.79918

Hajdu E, Desqueyroux-Faúndez R, Carvalho MD, Lôbo-Hajdu G, Willenz Ph (2013) Twelve new Demospongiae (Porifera) from Chilean fjords, with remarks upon sponge-derived biogeographic compartments in the SE Pacific. Zootaxa 3744(1): 1-64. https://doi. org/10.11646/zootaxa.3744.1.1 
Hajdu E, Desqueyroux-Faúndez R, Willenz Ph (2006) Clathria (Cornulotrocha) rosetafiordica sp. nov. from a south-east Pacific fjord (Chilean Patagonia) (Microcionidae: Poecilosclerida: Demospongiae: Porifera). Journal of the Marine Biological Association of the United Kingdom 86(5): 957-961. https://doi.org/10.1017/S0025315406013920

Hajdu E, Hooker Y, Willenz Ph (2015) New Hamacantha from Peru and resurrection of Zygherpe as subgenus (Demospongiae, Poecilosclerida, Hamacanthidae). Zootaxa 3926(1): 87-99. https://doi.org/10.11646/zootaxa.3926.1.3

Hajdu E, Peixinho S, Fernandez JCC (2011) Esponjas Marinhas da Bahia. Guia de Campo e Laboratório. Museu Nacional, Rio de Janeiro, 276 pp.

Hooper JNA, van Soest RWM (2002) Systema Porifera. A Guide to the Classification of Sponges. In: Hooper JNA, van Soest RWM, Willenz Ph (Eds) Systema Porifera. Springer Boston, 7 pp. https://doi.org/10.1007/978-1-4615-0747-5_1

Jaramillo KB, Reverter M, Guillen PO, McCormack G, Rodriguez J, Sinniger F, Thomas OP (2018) Assessing the Zoantharian diversity of the tropical Eastern Pacific through an integrative approach. Scientific Reports 8: e7138. https://doi.org/10.1038/s41598018-25086-4

Lee WL (1987) Guitarra abbotti and G. isabellae, new sponges from the Eastern Pacific. Proceedings of the Biological Society of Washington 100(3): 465-479.

Lendenfeld R von (1910) The Sponges. 2. The Erylidae. In: Reports on the Scientific Results of the Expedition to the Eastern Tropical Pacific, in charge of Alexander Agassiz, by the U.S. Fish Commission Steamer 'Albatross', from October, 1904, to March, 1905, Lieut. Commander L.M. Garrett, U.S.N., Commanding, and of other Expeditions of the Albatross, 1888-1904. (21). Memoirs of the Museum of Comparative Zoology at Harvard College 41(2): 261-324.

Miloslavich P, Klein E, Diaz JM, Hernández CE, Bigatti G, Campos L, Artigas F, Castillo J, Penchaszadeh PE, Neill PE, Carranza A, Retana MV, Diaz de Astarloa JM, Lewis M, Yorio P, Piriz ML, Rodriguez D, Yoneshigue-Valentin Y, Gamboa L, Martin A (2011) Marine biodiversity in the Atlantic and Pacific coasts of South America: Knowledge and gaps. PLoS ONE 6(1): e14631. https://doi.org/10.1371/journal.pone.0014631

Morrow CC, Cárdenas P (2015) Proposal for a revised classification of the Demospongiae (Porifera). Frontiers in Zoology 12: 1-7. https://doi.org/10.1186/s12983-015-0099-8

Pacheco C, Carballo JL, Cortés J, Segovia J, Trejo A (2018) Excavating sponges from the Pacific of Central America, descriptions and a faunistic record. Zootaxa 4370(5): 451-491. https://doi.org/10.11646/zootaxa.4370.5.1

Patil AD, Freyer AJ, Carte B, Taylor PB, Johnson RK, Faulkner DJ (2002) Haploscleridamine, a novel tryptamine-derived alkaloid from a sponge of the order Haplosclerida: An inhibitor of cathepsin K. Journal of Natural Products 65(4): 628-629. https://doi.org/10.1021/ np0105001

Recinos R, Pinheiro US, Willenz Ph, Hajdu E (2020) Three new Raspailiidae Hentschel, 1923 (Axinellida, Demospongiae) from Peru. Zootaxa 4778(3): 521-545. https://doi. org/10.11646/zootaxa.4778.3.5

Sarà M, Bavestrello G, Calcinai B (2000) New Tethya species (Porifera, Demospongiae) from the Pacific area. Zoosystema 22(2): 345-354. 
Schlick-Steiner BC, Steiner FM, Seifert B, Stauffer C, Christian E, Crozier RH (2010) Integrative Taxonomy: A Multisource Approach to Exploring Biodiversity. Annual Review of Entomology 55(1): 421-438. https://doi.org/10.1146/annurev-ento-112408-085432

Schuster A, Cardenas P, Pisera A, Pomponi SA, Kelly M, Wörheide G, Erpenbeck D (2018) Seven new deep-water Tetractinellida (Porifera: Demospongiae) from the Galápagos Islands - morphological descriptions and DNA barcodes. Zoological Journal of the Linnean Society 184(2): 273-303. https://doi.org/10.1093/zoolinnean/zlx110

Sim C-J, Bakus GJ (1986) Marine sponges of Santa Catalina Island, California. Occasional Papers of the Allan Hancock Foundation. Allan Hancock Foundation (New Series) 5: 1-23. Spalding MD, Fox HE, Allen GR, Davidson N, Ferdaña ZA, Finlayson M, Halpern BS, Jorge MA, Lombana A, Lourie SA, Martin KD, McManus E, Molnar J, Recchia CA, Robertson J (2007) Marine ecoregions of the world: A bioregionalization of coastal and shelf areas. BioScience 57(7): 573-583. https://doi.org/10.1641/B570707

Thiele J (1905) Die Kiesel- und Hornschwämme der Sammlung Plate. Zoologische Jahrbücher Supplement 6 (Fauna Chilensis III): 407-496. http://www.marinespecies.org/porifera/ porifera.php? $\mathrm{p}=$ sourcedetails $\&$ id $=8300$

Topsent E (1888) Contribution à l'étude des Clionides. Archives de Zoologie Expérimentale et Générale, 2 (5 bis): 1-165.

Topsent E (1891) Deuxième contribution à l'étude des Clionides. Archives de Zoologie Expérimentale et Générale 9: 555-592.

Topsent E (1895) Étude monographique des spongiaires de France. II. Carnosa. Archives de Zoologie Experimentale et Générale 3: 493-590.

van Soest RWM (1980) Marine sponges from Curaçao and other Caribbean localities. Part II. Haplosclerida. Studies on the Fauna of Curaçao and other Caribbean Islands 62(191): 1-173. van Soestt RWM, Boury-Esnault N, Hooper JNA, Rützler K, de Voogd NJ, Alvarez B, Hajdu E, Pisera AB, Manconi R, Schönberg C, Klautau M, Kelly M, Vacelet J, Dohrmann M, Díaz MC, Cárdenas P, Carballo JL, Ríos P, Downey R, Morrow CC (2020) World Porifera Database. https://doi.org/10.14284/359 [on 2020-04-03]

Vega C (2012) Composición y afinidades biogeográficas de esponjas (Demospongiae) asociadas a comunidades coralinas del Pacífico Mexicano. PhD Thesis, Instituto Politécnico Nacional, Mexico.

Willenz Ph, Hajdu E, Desqueyroux-Faúdez R, Lôbo-Hajdu G, Carvalho M (2009) Porifera. In: Häussermann V, Försterra G (Eds) Marine Benthic Fauna of Chilean Patagonia. Nature in Focus, Puerto Montt, 93-170.

Wilson HV (1904) The Sponges. Reports on an exploration off the west coasts of Mexico, Central and South America, and off the Galapagos Islands, in charge of Alexander Agassiz, by the US Fish Commission steamer" Albatross" during 1891, Lieut. Commander Z.L. Tanner, U.S.N., Commanding. Memoirs of the Museum of Comparative Zoology at Harvard College 30(1): 1-164. [pls 1-26]

Zea S (1987) Esponjas del Caribe colombiano. Catálogo Científico, Bogotá, 286 pp. 